UDC 658.8

DOI: https://doi.org/10.32782/2415-8801/2019-5.15

Rybachuk-Yarova Tetiana

Canidate of Economoc Sciences,

Associate Professor of the Department of Labour Economy and Management,

National University of Food Technologies

Polinchyk-Yarova Tetiana

Canidate of Economoc Sciences,

National University of Food Technologies

\title{
THE ASSORTMENT POLICY FORMATION AS AN ELEMENT OF THE ENTERPRISE COMPETITION STRATEGY
}

The article deals with the basic approaches to the conceptual apparatus "assortment policy". The term conclusions clarification has been made. It has been estimated that the assortment policy has been aimed at the number of enterprise goals solving in order to realize the main purpose of its activity. The effective and stable functioning has been achieved through the sale of the products range based on a combination of consumer needs and of business entities entrepreneurial capabilities. The assortment policy management system provides for the development of a strategy for each product group. Its implementation involves the range products managing by its life cycle stages using appropriate methods of its development. The number of factors that influence its formation have been identified. The ways of its realization have been considered. The integrated management evaluation model has been proposed.

Keywords: assortment policy, commodity portfolio management, model, strategy.

\section{ФОРМУВАННЯ АСОРТИМЕНТНОЇ ПОЛТТИКИ ЯК СКЛАДОВА КОНКУРЕНТНОЇ СТРАТЕГІї ПІДПРИЕМСТВА}

Рибачук-Ярова Т.В., Полінчик-Ярова Т.В.

У статті розглядаються основні підходи щцодо понятійного апарату «асортиментна політика». Зроблені висновки про необхіність уточнення терміну. Наведено, що асортиментна політика спрямована на вирішення ряду цілей підприємства задля реалізації основної мети його діяльності, а формування оптимального асортименту випливає на прибуток підприємства та інвестиційну привабливість компанії. Ефективне та стабільне функціонування досягається за рахунок реалізацї асортименту продукції на основі поєднання спожсичих потреб із підприємницькими можливостями суб'єктів господарювання. Система управління асортиментною політикою передбачає розроблення стратехії за кожною товарною групою. Ї̈ впровадження передбачас управління асортиментом продукції за етапами ї̈ життєвого циклу з використання відповідних методів ї̈ розроблення. Визначено ряд факторів, щцо впливають на ї̈ формування та розглянуті шляхи ї̈ реалізації. Підприємство має не тільки зосереджуватись на збільшенні обсягів продажу та частці ринку, воно має прагнути до домінування у вибраних сегментах ринку. Основним фактором, який характеризує асортиментну політику підприємства, с його здатність генерувати гроиові потоки, які багато в чому залежать від переваг обраного підприємства над його конкурентами. Необхідо, циоб підприємства розробили альтернативні напрямки асортименту (асортимент продукції) иляхом визначення номенклатури, асортименту та обсягів продажу. Запропонована модель комплексної оцінки управління на основі складових продуктового портфеля в таких галузях: конкурентоспроможність, стадія життевого циклу та ефективність функціонування продуктового портфеля. Результати дозволяють всебічно оцінити важливість товарної групи товарів у продуктовому портфелі підприєства та є основою для надання конкретних стратегічних та тактичних рекомендацій щодо складу та подальщого управління продуктовим портфелем у цілому.

Ключові слова: асортиментна політика, управління товарним портфелем, модель, стратегія.

\section{ФОРМИРОВАНИЕ АССОРТИМЕНТНОЙ ПОЛИТИКИ КАК СОСТАВЛЯЮЩАЯ КОНКУРЕНТНОЙ СТРАТЕГИИ ПРЕДПРИЯТИЯ}

Рыбачук-Яровая Т.В., Полинчик-Яровая Т.В.

В статье рассматриваются основные подходы к понятийному аппарату «ассортиментная политика». Сделаны выводы о необходиости его уточнения, показано, что ассортиментная политика направлена на реализацию ряда целей деятельности предприятия. Эффективное и стабильное функционирование достигается за счет реализации ассортимента продукции на основе сочетания потребительских потребностей с предпринимательскими возможностями субъектов хозяйствования. Система управления ассортиментной политикой предусматривает разработку стратегии по каждой товарной группе. Ее внедрение предполагает управление ассортиментом продукции по этапам ее жизненного цикла с использованием соответствующих методов. Определен ряд факторов, влияющих на ее формирование и рассмотрены пути ее реализации, предложена комплексная модель оценки управления.

Ключевые слова: ассортиментная политика, управление товарным портфелем, модель, стратегия. 
The problem formulation. The management conditions changing can stipulate the enterprise crisis state prevention that can cause not only reducing competitive demand, increasing prices for energy and raw materials, flawed regulation, but also internal factors such as imperfect management. The current economic growth in Ukraine makes it urgent to develop a crisis response, requires the development of theory and practice of management strategy. One of the ways of its realization is implementation of the appropriate assortment policy and formation of the commodity portfolio. The optimal range formation will reduce the economic fluctuations risk, maximize profits and save it for a long period, increase the company investment attractiveness.

The recent research and publications analysis. The leading foreign and Ukrainian scientists have devoted their research to the enterprise's assortment policy formation and its influence on the economic entities competitiveness. In particular, this issue was investigated by L. Bagiyev, B. Berman, F. Kotler, S. Blyznyuk and many other scientists $[1 ; 2 ; 3 ; 4]$. The studied literature analysis allows us to make the conclusion that there are different points of view on this issue. They can be divided into two groups. For the first scientists group the assortment policy is considered as the integral marketing, for the second - as the separate sphere of the management activity. From our point of view, the assortment policy is a set of means and methods of the enterprise managing commodity groups with the aim of forming its optimal composition, that can satisfy maximally the demand and ensure the enterprise profit.

The purpose of the article. The investigation of the modern assortment policy to economic entities formation, the determination of methods in the optimal assortment forming, the carrying out of complex evaluation.

The main material presenting. In order to ensure the effective enterprise functioning, the enterprise policy must be consistent with the overall enterprise development strategy. But the product portfolio consistency problems and its components are crucial in the current conditions. The enterprises management must be adaptive, that is, providing timely consideration of changes in the influence of environmental factors, resource potential, financial status and other parameters of production management and timely response to these changes. Impact factors have different directions. This is first of all demand for products, brand recognition, channels of production distribution, products profitability, the level of organization in production, the logistical base state, etc.

There are two ways to expand your product range: the extension or the saturation.

1. The extension of the product range. The extension of the assortment occurs when the enterprise goes beyond that it currently produces.

2. The saturation of the product range. The product range increase by adding new models to its existing frameworks.

Reasons for range saturation:

1) the extra profit making;

3) the unused production capacity attracting;

4) the desire to become the leading company with the comprehensive range;

5) the eliminate gaps to prevent competitors [5].

The optimal range formation is advisable to make in stages.
The first stage. The analysis of market dynamics and demand patterns. The department, that is responsible for the assortment managing (it is the marketing service), initiates the optimization process with established frequency. The marketing department analyses the dynamics of sales by product groups (individual products), assesses the prospects of changing demand and competition in the segments that the company has been presented or where it is going to present with their products (services). Basing on the received information, the marketing experts prepare some options for the range structure changing, aimed at the improving customer satisfaction, the company's competitive position strengthening and the market share increasing.

The second stage. The financial analysis of developed proposals. The planning and economic service analyses the financial indicators by product groups or individual products and makes its conclusions about the change in the range structure.

The third stage. The approval of the final assortment structure version. The working group, that consists of marketing specialists, economic and other departments specialists (production specialists, purchasing specialists, logistics specialists), develops and coordinates the final variant of the decision on the company product range optimization [6].

The enterprise should not only focus on the increasing sales and the market share, it should strive for the dominance in selected market segments. The main factor that characterizes the enterprise's assortment policy is its ability to generate the cash flows that depend largely on the advantages of the selected enterprise over its competitors. It is necessary for the enterprises to develop the alternative assortment directions (product portfolio) management, by the defining nomenclature, assortment and sales volumes.

The development of the commodity portfolio comprehensive assessment methodology is one of the areas to realize this issue, that the industry development state and tendencies, the features of functioning enterprises in market conditions, the structure of supply and the consumption products level would take into account, and would be the basis for building strategy in the commodity policy enterprises managing for the long term.

- The proposed complex evaluation enterprise portfolio management methodology allows:

- to evaluate the product portfolio quality;

- to determine the directions priority in the product portfolio enterprise development;

- to develop the commodity policy enterprise strategy (the set of strategies)

According to the author's methodology, the company's product portfolio comprehensive assessment is an integrated assessment of the product portfolio components in the following areas: the competitiveness, the life cycle stage and the product portfolio market functioning efficiency.

The combining metrics into the one estimate is based on the "integral Gj estimate", which is defined as the arithmetic mean of the standardized values of zij" [7].

In accordance to the proposed methodology, the basis of comparison is the different weighted indicators average level. In this regard, the complex estimate is a multidimensional mean and it is determined by the weighted arithmetic formula: 


$$
G_{j}=\sum_{1}^{n} z_{i j} \omega_{i},
$$

whereas: $\mathrm{G}_{\mathrm{j}}$ - the integral evaluation; $j$

$z_{i j}$ - The expert estimates based on the custom scales or on the standardized values;

$\omega_{i}-$ authority $i$ - research direction, $\Sigma \omega_{i}=1$;

$\mathrm{i}$ - research direction;

$\mathrm{j}$ - the study object;

$\mathrm{m}$ - the number of the research types.

The authority factor, that determines each line research authority for a commodity portfolio, it is based on the phenomenon essence theoretical analysis in each authority specific study $i$ - characteristic $\left.\left(\omega_{i}\right)\right)$ is determined by the expert-statistical method [8].

The comprehensive commodity performance portfolio evaluation is made by constructing a matrix (Table 1) according to the algorithm.

The first stage. The matrix will have been built, where the value of the choice strategy development commodity portfolio recommendation by the competitiveness indicators are written separately by the research types in columns (3) - (5), by stage of product development (concept of "product life cycle") and by the efficiency of functioning of the object of research in the market (ABC-XYZ analyse).

Each authority study direction has been written by the expert judgment method determining to the columns (6) (8) of the i-direction study.

The second stage. The study object for each type of study is assigned a rating of importance. The significance assessments are made by using the peer review method.

The experts are invited to evaluate the importance of each factor characterizing the level of products competitiveness on the market, the level of its functioning on the market and the stage of its development. It will be necessary for the experts to rank the degree of importance factors and to produce an assessment by evaluating, that they consider as a rational. The enterprises competitive position indicators for the specific industry have been determined by the market share criteria in comparison with the competitors, the brand information, the breadth of product range, the level of product quality, the technological capabilities and the level of distribution. The product market attractiveness has been determined by using the following criteria: the market growth rate per year, the barriers to entry, the barriers to exit, the seasonal fluctuations, the industry profitability, the market life cycle stage (product category, products), the intensity competition, the non-price competition, the customer concentration, the government influence, the society. The value of each criteria and its weight have been determined by the level of:

- 0 - there is no influence of the criteria on the enterprise competitive position;

- 0,2 - the criteria competitive position of the company impact is weak;

- $0,4-$ the criteria competitive position of the company impact is negligible;

- 0,5 - the criteria competitive position of the company impact is middle;

- 0,6 - the criteria competitive position of the company impact is considerable;

- 0,8 - the criteria competitive position of the company impact is strong;

- 1 - the criteria competitive position of the company impact is very strong.

The total weight rating should be equal to one.

The relative importance of each individual factor has been determined by the normalized unit priority matrix estimation with the corresponding to its own vector. The competitiveness importance assessments (the «GE/McKinsey» matrix) and the market product portfolio performance have been determined by the sector where the study object is located. This research object has been assigned with the corresponding score in the range of 9 to 1 , where

Table 1. The matrix of the commodity portfolio enterprise complex estimation

\begin{tabular}{|c|c|c|c|c|c|c|c|c|c|c|c|c|c|c|c|c|c|c|}
\hline \multirow[b]{2}{*}{ № } & \multirow[b]{2}{*}{$\begin{array}{l}\text { The product } \\
\text { groups }\end{array}$} & \multicolumn{3}{|c|}{$\begin{array}{l}\text { The obtained } \\
\text { result in the study } \\
\text { direction }\end{array}$} & \multicolumn{3}{|c|}{$\begin{array}{c}\text { The authority } \\
\text { degree } \\
\text { estimates }\end{array}$} & \multicolumn{3}{|c|}{$\begin{array}{l}\text { The absolute } \\
\text { deviation from } \\
\text { the mean value }\end{array}$} & \multicolumn{3}{|c|}{$\begin{array}{l}\text { The relative } \\
\text { deviation from } \\
\text { the mean value }\end{array}$} & \multicolumn{3}{|c|}{$\begin{array}{l}\text { The } \\
\text { comprehensive } \\
\text { assessment of } \\
\text { the particular } \\
\text { research area }\end{array}$} & \multirow[b]{2}{*}{ 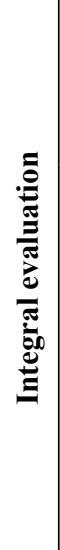 } & \multirow[b]{2}{*}{ 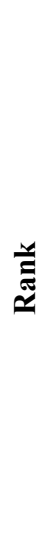 } \\
\hline & & 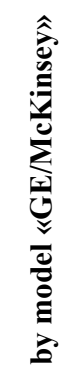 & 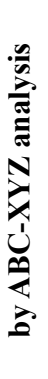 & 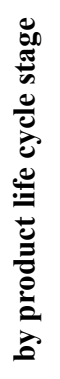 & 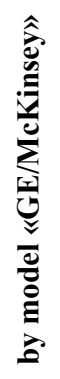 & 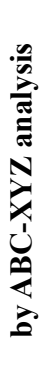 & 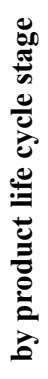 & 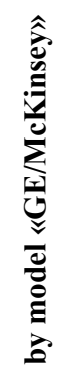 & 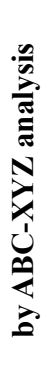 & 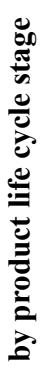 & 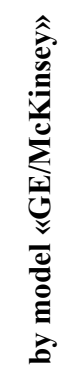 & 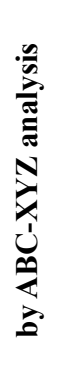 & 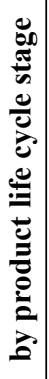 & 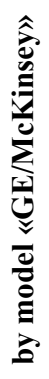 & 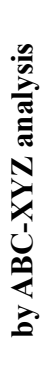 & 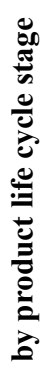 & & \\
\hline 1 & 2 & 3 & 4 & 5 & 6 & 7 & 8 & 9 & 10 & 11 & 12 & 13 & 14 & 15 & 16 & 17 & 18 & 19 \\
\hline \multicolumn{19}{|l|}{1} \\
\hline \multicolumn{19}{|l|}{2} \\
\hline \multirow[t]{2}{*}{$\mathrm{n}$} &.. & $\ldots$ & $\ldots$ & $\ldots$ & $\ldots$ & $\ldots$ & $\ldots$ & $\ldots$ & $\ldots$ & $\ldots$ & & & & & & & & \\
\hline & Together & $\mathrm{x}$ & $\mathrm{x}$ & $\mathrm{x}$ & & & & $\mathrm{x}$ & $\mathrm{x}$ & $\mathrm{x}$ & $\mathrm{x}$ & $\mathrm{x}$ & $\mathrm{x}$ & $\mathrm{x}$ & $\mathrm{x}$ & $\mathrm{x}$ & $\mathrm{x}$ & $\mathrm{x}$ \\
\hline & Average value & $\mathrm{x}$ & $\mathrm{x}$ & $\mathrm{x}$ & & & & $\mathrm{x}$ & $\mathrm{x}$ & $\mathrm{x}$ & $\mathrm{x}$ & $\mathrm{x}$ & $\mathrm{x}$ & $\mathrm{x}$ & $\mathrm{x}$ & $\mathrm{x}$ & $\mathrm{x}$ & $\mathrm{x}$ \\
\hline \multicolumn{5}{|c|}{$\begin{array}{l}\text { The weight of the "i" study direction } \\
\text { (total = } 1.0 \text { ) }\end{array}$} & & & & $\mathrm{x}$ & $\mathrm{x}$ & $\mathrm{x}$ & $\mathrm{x}$ & $\mathrm{x}$ & $\mathrm{x}$ & $\mathrm{x}$ & $\mathrm{x}$ & $\mathrm{x}$ & $\mathrm{x}$ & $\mathrm{x}$ \\
\hline
\end{tabular}

The " $x$ " - indicators are not calculated 
9 is the maximum score, 1 is the minimum. The research object assessment importance on the concept of "product life cycle" has been carried out according to the relevant stage value of the research object development. It has been suggested to use the scale from 5 to 1 , where scores are:

5 - the demand growth stage;

4 - the maturity stage;

3 - the saturation stage;

2 - the stage of decline;

1 - the stage of the severe decline.

The concordance of experts' opinions on the coefficient of concordance was from 0,57 to 0,63 , and the calculated value $\chi^{2}-$ Pearson's criterion - from 8,52 to 9,63 . The tabular value $\chi^{2}$ - Pearson's criterion $\chi^{2}=3,24$, the normative value of the coefficient of concordance $\mathrm{WH}_{\mathrm{H}}=0,5$. As in all previous expert-rated positions, $W>W H$ and $\chi^{2}$ calculations $>\chi^{2}$ table - therefore, the experts' opinions are agreed and their results can be used in further calculations.

The third stage. The importance degree sum and its average value have been calculated separately for each study object and for each type of the study.

The fourth stage. The absolute deviation has been calculated for each study object and for each type of the study.

The fifth stage. The relative variance has been calculated for each study object by type of the study.

The sixth stage. The integral score for each study area has been determined. The integral estimate, that is the multidimensional mean, has been determined by the form of the weighted arithmetic mean.
The seventh stage. The common integral estimate has been founded:

$$
G=\sum_{1}^{m} G_{j}
$$

where: $\mathrm{G}$ - the total integral score;

$\mathrm{j}$ - the study object;

$\mathrm{m}$ - the number of the research types.

The eighth stage. The research object rank, that determines the importance of a research object in an enterprise product portfolio, has been exposed. The integrated evaluation of the research objects has been sorted in descending order for this purpose.

The result allows us to evaluate comprehensively the importance of the product group in the enterprise product portfolio and is the basis for providing specific strategic and tactical recommendations for the composition and further management of the product portfolio as a whole.

Conclusions. The strategic development of the company involves the formation range optimization at the different life cycle stages and its evaluation. The manufactured products range optimizing is one of the ways to increase the enterprise efficiency. The optimal portfolio saves resources for the new destinations development and increases the enterprise mobility. The proper optimization can greatly increase profits with the constant or the fewer products releasing. The decision to optimize the assortment and its structure has to be subordinated first of all with the strategic enterprise goals.

1. Bagiev G.L. Osnovyi sovremennogo marketinga : ucheb.-naglyad. posobie. Sankt-Peterburg : Izd-vo S.-Peterb. gos. un-ta ekonomiki i finansov, 2002. $280 \mathrm{~s}$.

2. Berman B., Evans Dzh. Roznichnaya torgovlya: strategicheskiy podhod; per. s angl. Moskva, 2003.1183 s.

3. Kotler. F. Osnovyi marketinga; per. s angl. Moskva : Izdatelskiy dom «Vilyams», 2005. 656 s.

4. Blyzniuk S.V. Marketynh v Ukraini: problemy stanovlennia ta rozvytku : monohrafiia. Kyiv : Politekhnika, 2003. $384 \mathrm{~s}$

5. Bardash M.S., Khomenko O.I. Asortymentna polityka pidpryiemstva ta shliakhy yii vdoskonalennia. Efektyvna ekonomika. 2016. № 11. URL: http://www.economy.nayka.com.ua/?op=1\&z=5288 (accessed: 15.11.2019).

6. Repich T.A. Udoskonalennia upravlinnia asortymentom na suchasnykh pidpryiemstvakh v umovakh kryzy. Kharchova promyslovist. 2009. № 8. S. 109-112.

7. Yerina A.M., Zakhodzhai V.B. Metodolohiia naukovykh doslidzhen : navch. posib. Kyiv : Tsentr navch. lit., 2004. $212 \mathrm{~s}$.

8 Shmoilova R.A. Praktykum po teoryy statystyky : ucheb. Posobye. Moskva : Fynansbl y statystyka, 2006.416 s.

1. Багиев Г.Л. Основы современного маркетинга : учеб.-нагляд. пособие. Санкт-Петербург : Изд-во С.-Петерб. гос. ун-та экономики и финансов, 2002. 280 c.

2. Берман Б., Эванс Дж. Розничная торговля: стратегический подход; пер. с англ. Москва, 2003.1183 с.

3. Котлер. Ф. Основы маркетинга; пер. с англ. Москва : Издательский дом «Вильямс», 2005. 656 с.

4. Близнюк С.В. Маркетинг в Украӥні: проблеми становлення та розвитку : монографія. Київ : Політехніка, 2003. $384 \mathrm{c}$.

5. Бардаш М.С., Хоменко О.І. Асортиментна політика підприємства та шляхи ї̈ вдосконалення. Ефективна економіка. 2016. № 11. URL: http://www.economy.nayka.com.ua/?op=1\&z=5288 (15.11.2019).

6. Репіч Т.А. Удосконалення управління асортиментом на сучасних підприємствах в умовах кризи. Харчова промисловість. 2009. № 8. С. 109-112.

7. Єріна А.М., Заходжай В.Б. Методологія наукових досліджень : навч. посіб. Київ : Центр навч. літ., 2004. $212 \mathrm{c}$.

8 Шмойлова Р.А. Практикум по теории статистики : учеб. Пособие. Москва : Финансы и статистика, 2006. $416 c$.

E-mail: ribachuk@gmail.com 